\title{
Predicting Recovery of Lower Extremity Sports Injuries in Primary Care
}

\author{
F. Baarveld ${ }^{*}, 1$, B.J. Kollen ${ }^{2}$ and K.H. Groenier ${ }^{1}$ \\ ${ }^{I}$ Department of General Medicine of Groningen University, the Netherlands \\ ${ }^{2}$ Research Bureau, Isala klinieken Zwolle, the Netherlands
}

\begin{abstract}
Objectives: To survey patient characteristics and elements of primary care that contribute to the recovery of patients with non-acute sports related injuries to the lower extremity.

Methods: Prospective observational study based on information on patient characteristics, physicians' care and recovery gathered with questionnaires from physicians and patients during the first consultation and from patients at 1, 3, 6 and 12 months after inclusion.

Results: Physicians and patients response rates of questionnaires during the entire study period amounted to at least 90 percent. At one month athletically competitive patients with symptoms of $\leq 3$ months duration prior to consultation showed no or less sport discontinuation as a result of the injury than athletically non-competitive patients with symptoms of $>3$ months duration, while at 12 months male patients were more likely to continue sports activities than female patients. Overall, sport discontinuation due to the injury decreased significantly over time.

Conclusion: Athletically competitive patients with symptoms of 3 months duration or less were least likely to discontinue their sports participation at one month. No elements of administered primary care were identified for the accurate prediction of sport discontinuation in the GP office. In general, sport discontinuation decreased gradually over time.
\end{abstract}

\section{INTRODUCTION}

Sports in general play an important role in today's society. In the Netherlands about 8 of its 16 million people participate in sports activities at an organized or non-organized level [1]. In addition to its health benefits, concomitant injuries may occur. In this country annually 2.7 million sports injuries are reported, of which 1.1 million are presented to the office of a health care facility [2]. At present rather than sports injury the comprehensive term sports related injury is used [3]. This term denotes any injury that affects the individuals' ability to engage into sports activities irrespective of where this injury was sustained. It therefore also incorporates injuries sustained during non-sports activities.

The incidence of non-acute sports related injuries is likely to increase, because in particular the older segment of people from society becomes gradually more involved in sports activities [4]. This older population mainly participates in recreational sports, such as fitness exercises, jogging and cycling [5]. Gradually developing sports related injuries are especially common as a sequel to fitness exercises and jogging, whereas these injuries also tend to relapse more frequently than acute injuries [6]. To date no scientific data on non-acute sports related injuries in primary care is available. A MedLine and Embase literature search yielded no suitable references of primary care studies conducted on sports related injuries. It therefore remains uncertain as to which characteristics are responsible for this recovery. Knowledge of these factors may contribute to the development of primary care protocols and guidelines. Available knowledge

\footnotetext{
*Address correspondence to this author at the Department of General Medicine of Groningen, University, The Netherlands;

E-mail: f.baarveld@med.umcg.nl
}

on sports related injuries may not apply to this population of primary care patients, because this knowledge is derived from the characteristics of patients seeking specialist care. Only a small percentage of primary care patients with nonacute sports related injuries to the lower extremity are referred to a specialist, such as sports physician $(3.3 \%)$ and orthopaedic surgeon (8.3\%) [7]. These patients suffer from the most persistent injuries [8]. Therefore, we conducted a study to address the following question. Which patient characteristics or elements in physicians' care contribute to the recovery of patients with non-acute sports related injuries to the lower extremity?

\section{METHODS}

This prospective observational study is part of a longitudinal unblinded randomized controlled trial, in which the primary care provided by family and sports physicians (operating in a primary care setting) was studied in patients with non-acute sports related injuries to the lower extremity [7]. This study was conducted between 2000 and 2002 in three northern Dutch regions (Heerenveen, Zwolle and Groningen). Within each region patients were recruited for this trial during a period of 6 months. As these recruitment periods were consecutive, the total enrolment period amounted to one and an half year overcoming any possible injury related seasonal impacts.

Following obtaining informed consent, opaque envelopes were used for the randomization procedure of patients. Subsequently, patients consulted the allocated family or sports physician at the primary care facility site within a week.

In this study most injuries were diagnosed as sprains and distorsions. In addition, osteochondropathies, patellar femoral pain syndrome, meniscal tears, tendonitis or tendopathies 
were diagnosed. Most frequently, the physicians offered advice (e.g. rest, exercise, cooling, moist heat, alternative sports), explained the nature of the injury, prescribed medication, brace, tape and/or used a 'wait and see' policy, but also referred patients to physiotherapy services or provided progressive workout schedules. In a minority of cases, patients were referred to an orthopaedic surgeon or sports physician for further evaluation.

For this observational study information was obtained from questionnaires completed by all respondents, including family and sports physicians and their patients.

\section{Study Population}

\section{Family Physicians}

Regional clusters of family physicians operating in three northern regions in the Netherlands were approached and their members invited to participate in this trial. In this way the participation of only sports-minded family physicians was avoided. Within these clusters most physicians operate from solo practices. Patients were enrolled into the trial by 83 family physicians of which 59 were allocated to provide primary care by the randomization procedure.

\section{Sports Physicians}

Within each region only one sports physician was operating clinically during this trial in the northern Netherlands. All three sports physicians accepted the invitation to participate.

\section{Patients}

Participating patients were recruited from the group of patients that consulted their family physician for a non-acute sports related injury to the lower extremity.

\section{Inclusion Criteria}

Inclusion of patients with sports related injuries was based upon satisfying the following criteria. The injury was sustained at least two weeks prior to consulting the family physician; the injury was confined to the lower extremity and was presented as a first event. No age limit was included.

\section{Dependent and Independent Variables}

The outcome variable constitutes the extent of sport discontinuation measured from the first month following inclusion onwards. This variable consists of a 5 point ordinal scale that varies from 'stopped all sports activities' (1) to 'no sport discontinuation' (5) and was dichotomized to enable logistic regression analysis (stopped all sport activities, more and same sport discontinuation were defined as 0 ; less and no discontinuation was defined as 1).

This dependent variable was related to the following independent variables: Duration of symptoms before the first consultation of the physician (varies between ' $2-3$ weeks' and 'more than 12 months'), sports objective (competitive/noncompetitive), type of sport, work-out frequency (varies between 'less than 1' and 'more than 4' times a week), patients' age, patients' gender, physicians' professional experience (expressed in number of years), relevant postgraduate courses attended by the physician (yes/no), physicians' administered care (subdivided into instruction, clarification, therapy and referral) and physiotherapy (yes/no).
In total 7 questionnaires were administered. These questionnaires were completed during the first consultation by the family physician, sports physician and patient and at 1, 3, 6 and 12 months by the patient. The research proposal was approved by the STEG ethnics committee in Amsterdam.

\section{Statistical Analysis}

Logistic regression models were developed to predict outcome using cross-sectional information from the respondents at each individual time point of measurement separately. Variable entering the model was based upon the 'best subset' stepwise selection technique at $\alpha=0.05$. Longitudinal changes within sport discontinuation were tested with GLM statistics for repeated measurements. Compliance with the assumptions of the multivariable models was tested for all variables involved. In the event the data did not fit the assumptions of the model, independent variables were dichotomized based upon their median or feature present or absent.

\section{RESULTS}

Fifty-nine family physicians, 3 sports physicians, 231 patients participated in this study. Patient characteristics are presented in Table $\mathbf{1}$. The response rate of questionnaires gradually diminished from 100 percent at the first consultation to 90 percent at 12 months after inclusion. Following data checking the percentage of missing values among the independent variables varied between 10 percent for 2 variables (sports objective and relevant postgraduate courses) and no missing values for 5 variables (gender and age of patient, duration of symptoms before first consultation of physician, physicians' care and physiotherapy). Moreover, significance was found in less than 5 percent of the cases in the relationship between missing or no missing data and other determinants. Therefore, no attempt was made to estimate the missing values.

\section{Table 1. Baseline Characteristics of Participating Patients}

\begin{tabular}{|l|c|c|}
\hline \multicolumn{1}{|c|}{ Characteristic } & Parameters & N \\
\hline \hline Age: mean (sd) & $32.8(13.7)$ & 231 \\
\hline Gender: \% male & $67.5 \%$ & 231 \\
\hline Body mass index: mean (sd) & $23.6(3.8)$ & 217 \\
\hline Type of sport: mode & Soccer & 221 \\
\hline Sports objective: \% non-competitive & 60.6 & 213 \\
\hline Work-out frequency: median & $2 \mathrm{x}$ & 227 \\
\hline Duration of each work out: median & 1.5 hours & 224 \\
\hline Period of sport discontinuation: median & $1-3$ months & 193 \\
\hline $\begin{array}{l}\text { Duration of symptoms prior to first consultation: } \\
\text { median }\end{array}$ & $6-13$ weeks & 231 \\
\hline Site of injury: mode & Knee & 231 \\
\hline
\end{tabular}

At one month athletically competitive patients with symptoms of $\leq 3$ months duration prior to consultation showed significance for no or less sport discontinuation, while at 12 months this only applied to male patients. At 3 and 6 months no variables showed significance (Table 2).

Sport discontinuation decreased significantly over time ( $\mathrm{F}=20.84, p=0,000)$, in particular between first and third 
Table 2. Logistic Prediction Model for Sport Discontinuation at 1, 3, 6 and 12 Months. Only Significant Variables are Presented

\begin{tabular}{|c|c|c|c|c|c|}
\hline \multirow{2}{*}{ Sport Discontinuation } & \multirow{2}{*}{ Predictor } & \multicolumn{3}{|c|}{ Parameters } \\
\cline { 3 - 6 } & & b & $\boldsymbol{p}$ & OR & $\mathbf{9 5 \%}$ CI \\
\hline \hline \multirow{2}{*}{ At month 1 } & Dichotomized duration of symptoms & -0.63 & 0.04 & 0.53 & $0.29-0.96$ \\
\cline { 2 - 7 } & Sports objective & 0.66 & 0.02 & 1.94 & $1.09-3.45$ \\
\hline At month 12 & Gender of patient & -0.70 & 0.04 & 0.50 & $0.26-0.95$ \\
\hline
\end{tabular}

${ }^{1}$ Parameters: $\mathrm{b}$ - b coefficient; $p$ - level of significance; OR - odds ratio; CI - confidence interval.

${ }^{2}$ Duration of symptoms: $\leq 3$ months/ $>3$ months.

months $(p=0,000)$ and sixth and twelfth months $(p=0,008)$ measurements. This decline was linear $(\mathrm{F}=37,59, p=0,000)$ as well as cubic $(\mathrm{F}=9,44, p=0,002)$.

\section{DISCUSSION}

This study found factors at one and twelve months that accurately estimated the probability of incurring no or less sport discontinuation. Athletically competitive patients with symptoms of 3 months duration or less were least likely to discontinue their sports participation at one month. This category of patients with no chronic symptoms probably represent the most motivated participants with least severe injuries among the study population. However, no elements of primary care were identified for the accurate prediction of sport discontinuation in the GP office. In other words, family physician interventions did not appear to affect sport discontinuation as competitiveness, prior duration of symptoms and gender constitute characteristics that are not amenable to a physicians' primary care intervention. The difference in sport discontinuation between males and females observed at 12 months may be considered an artefact because a similar difference was not found during previous months and no plausible explanation can be given for this finding.

In this observational study a gradual decline in sport discontinuation was observed in all patients. This sport discontinuation eventually faded away almost completely. Most probably this decline represents the healing effect of time. It is unlikely this decline is generated by the physicians' care, because on average patients consulted their physician only twice.

This study suffered from some potential limitations. First, no clinimetric testing was conducted prior to the administration of questionnaires. As a consequence reliability, validity and responsiveness of these tools have not been established. Most likely this omission would have had no bearing on our findings as studies with methodological shortcomings tend to overestimate the accuracy of prediction [9]. In addition, the OR confidence intervals entail some uncertainty about the accuracy of prediction and as a result these findings need to be interpreted with some caution.

Because of the predominance of knee injuries in our population these results may not fully apply to other injuries in lower extremities.
Larger scaled trials with more subjects are needed to accurately estimate risk factors for sport discontinuation in this rather heterogeneous population.

Moreover, in the process of dichotomizing dependent and independent variables relevant clinical cut-off points were elected. However, these cut-off points are arbitrary to some extent. For the selection of variables intended to estimate the probability of achieving no or less sport discontinuation the models used in this study may have lacked specificity. Disorder specific models are more accurate and therefore more informative. This study was unable to provide such a model because the diagnoses made by the participating family physicians were too much symptom derived and lacked specificity [10].

\section{ACKNOWLEDGEMENT}

The authors wish to thank dr. J. Schuling for his critical comments on the manuscript.

\section{REFERENCES}

[1] Schmikli SL, Backx FJG, Bol E. Sportblessures nader uitgediept. Bohn Stafleu Van Loghum, Houten/Diegem 1995.

[2] Hulshof NA, van Essen GA, Andela M, Friele RD. Patiënten over preventie door hun huisarts. Huisarts Wet 1998; 41: 117-20.

[3] Sport, bewegen en gezondheid. Naar een actief kabinetsbeleid ter vergroting van de gezondheid door en bij sport en beweging. Ministerie van Volksgezondheid, Welzijn en Sport. September 2001.

[4] Rapportage Sport 2003. Sociaal Cultureel Planbureau. Den Haag, april 2003.

[5] Schmikli SL, de Wit MAJP, Backx FJG. Sportblessures driemaal geteld. Kerncijfers en trends uit een landelijk onderzoek naar sportblessures in Nederland. Arnhem: NOC*NSF; 2001.

[6] Keizer SB, Hammacher ER, Backx FJG, Langenhorst AMWW, Hendriks ERHA, Mosterd WL. Het klinisch sportspreekuur, de eerste ervaringen. Ned Tijdschr Geneeskd. 1996: 140: 1548-51.

[7] Baarveld F, van Enst GC, Schuling J, Bosveld HEP, Meyboom-de Jong B. Behandeling en Verloop van Niet-acute Sportgerelateerde Problemen van de Onderste Extremiteit. Een Vergelijkend Onderzoek tussen Huisarts en Sportarts. In: Sportgerelateerde Problemen in de Huisartspraktijk. Frank Baarveld. Elsevier gezondheidszorg, Maarsen 2004.

[8] Baarveld F, ter Steege MDJ, van Enst GC. Van huisarts naar sportarts Een onderzoek naar het verwijspatroon van sportgerelateerde problemen door de huisarts naar de intramuraal werkzame sportarts. Geneesk Sport 2004; 37: 64-68.

[9] Lijmer JG, Mol BW, Heisterkamp S, et al. Empirical Evidence of Design-Related Bias in Studies of Diagnostic Tests. JAMA 1999: 282 (11): 1061-66.

[10] Baarveld F, Schuling, J. Diagnosis in primary care. Diagnosis and treatment in non-acute sports related injuries to the lower extremity. In: Sportgerelateerde Problemen in de Huisartspraktijk. Frank Baarveld. Elsevier gezondheidszorg, Maarsen 2004. 